\title{
ACCUMULATION OF TOTAL ANTHOCYANINS IN WHEAT GRAIN
}

\author{
ALŽBETA ŽOFAJOVÁ ${ }^{1 *}$, IVANA PŠENÁKOVÁ ${ }^{2,3}$, MICHAELA HAVRLENTOVÁ ${ }^{1}$ \\ MICHAELA PILIAROVÁ2
}

\author{
${ }^{1}$ Plant Production Research Center Piešt'any \\ ${ }^{2}$ University of SS. Cyril and Methodius in Trnava \\ ${ }^{3}$ Constantine the Philosopher University in Nitra
}

ŽOFAJOVÁ, A. - PŠENÁKOVÁ, I. - HAVRLENTOVÁ, M. - PILIAROVÁ, M.: Accumulation of total anthocyanins in wheat grain. Agriculture (Pol’nohospodárstvo), vol. 58, 2012, no. 2, pp. 50-56.

In the recent years, for specific goals of utilization, winter wheat breeding has been aimed on increasing total anthocyanins concentration in winter wheat grains considering their high antioxidant activity. The aim of research was to evaluate grain colour development in four wheat genotypes (ANK 28A and $62 / 0$ purple pericarp, UC 66049 blue aleurone and Ilona red pericarp) during grain filling period. Grain samples from two replications of field experiment, established in the vegetation $2010 / 11$, were taken in five to six sampling times. Total anthocyanins concentration was determined by spectrophotometer. The genotypes responded differently to the dynamics of total anthocyanins accumulation during grain filling. The process

Key words: wheat, grain color, anthocyanins, breeding

Anthocyanins are generally specified as bioactive, non-nutritional compounds, responsible for antioxidant (Kong et al. 2003) and UV/photoprotective functions (Ryan et al. 2001). They have been shown to have some beneficial health effects on oxidative damage (Prior \& $\mathrm{Wu}$ 2006) and dispose of higher antioxidant activity than vitamins $\mathrm{C}$ and $\mathrm{E}$ and appear to have a synergic effect on vitamin $\mathrm{C}$ and other flavonoids (Duthie et al. 2006). Beneficial effect of antioxidants on health promoting is believed to be achieved through several possible mechanisms, such as directly reacting with and quenching free radicals, chelating transition metals, was described by linear and also by polynomial regression on the number of days post anthesis. Genotypes with purple pericarp reached the highest total anthocyanins concentration on the $22^{\text {nd }}$ day post anthesis with increasing and decreasing before and after this sampling time, respectively. At maturity the highest total anthocyanins had UC $66049(193.38 \mathrm{mg} / \mathrm{kg})$. Newly bred genotype $62 / 0$ had similar concentration $(34.50 \mathrm{mg} / \mathrm{kg})$ as its parent ANK $28 \mathrm{~A}(37.80 \mathrm{mg} / \mathrm{kg})$. At maturity, registered cultivar Ilona was about $93.7 \%$ lower in total anthocyanins concentration compared to ANK 28A. Significant variability in total anthocyanins concentration indicated that breeding for their increasing is possible.

reducing peroxides, as well as stimulating the antioxidative defense enzyme system (Kong et al. 2003).

Epidemiological studies reveal that number of diseases including cancer, diabetes, Alzheimer's disease, coronary heart diseases, and aging have been found to be associated with oxidative stress (Baublis et al. 2000). Anthocyanins have gained attention due to their anti-inflammatory (Bowen-Forbes et al. 2010), antimutagenic and anticarcinogenic properties (Wang \& Stoner 2008). Other biological activities are antibacterial, hepatotoxicity and induction of apoptosis (Mazza 2007).

\footnotetext{
Ing. Alžbeta Žofajová, PhD., RNDr. Michaela Havrlentová, PhD., Plant Production Research Center Piešt’any, 92168 Piešt’any, Bratislavská cesta 122, Slovak Republic. E-mail: zofajova@vurv.sk (*Corresponding author), havrlentova@vurv.sk Ing. Ivana Pšenáková, Department of biotechnologies, Faculty of Natural Sciences, University of SS. Cyril and Methodius in Trnava, 91701 Trnava, Slovak Republic. E-mail: psenakova@ucm.sk Mgr. Michaela Piliarová, Department of biotechnologies, Faculty of Natural Sciences, University of SS. Cyril and Methodius in Trnava, 91701 Trnava, Slovak Republic
} 
Wheat cultivars with high level of anthocyanins have potential for using as a dietary source of bioactive material to prevent diseases and promote health in the functional food industry (Revanappa et al. 2011). Anthocyanins participate in the formation of non-specific disease resistance in plants (Treutter 2006) and plant protection against biotic and abiotic stress factors (Khlestkina et al. 2011). The environment, such as high light intensity, low temperature, high salinity and/or drought stress, affects their production (Chalker-Scott 1999).

Blue, purple, red, white, or orange coloration of plant tissues and organs in wheat and other cereals is done by anthocyanins (Abdel-Aal et al. 2006). Anthocyanins are flavonoids classified within phenolic phytochemicals (Liu 2004). They represent a big group of water soluble natural colorants and from the structural point of view anthocyanins are glycosides composed of polyhydroxyled or polymethoxyled 2-phenylbenzopyrilium skeleton with hydroxyl and methoxyl groups in the B-ring. The structural variation extends bounded sugars such as pentoses-xylose, arabinose, rhamnose, fructose and hexoses-galactose, glucose (Hosseinian et al. 2008). The most occurred anthocyanins in wheat grain are: cyanidin (responsible for the red color), delphinidin (blue color), peonidin (blue color), pelargonidin (orange and red color), petunidin (purple color), and malvidin (purple color) (Oomah \& Mazza 1999). The amount of anthocyanins is rapidly increased during maturing; nevertheless in maturity the amount drops (Knievel et al. 2009).

The aim of research was to evaluate the development of the grain color during grain filling in selected wheat genotypes of different grain color.

\section{MATERIAL AND METHODS}

Selected winter wheat genotypes were evaluated in the field experiment established in the Plant Production Research Center Piestany by randomized complete block design in two replications in the vegetation 2010/11. Evaluated set consisted of ANK 28A, spring form, purple pericarp, which is the isogenic line of Novosibirskaya 67; UC 66049, spring form, blue aleurone, that originated from USA (Qualset et al. 2005); newly bred genotype 62/0, winter form, purple pericarp, that originated from breeding of color wheat on the Research and Breeding Station at Viglas-Pstrusa and control winter wheat cultivar Ilona with standard red grain color. From milk to grain physiological maturity according to procedure published by Knievel et al. (2009) (in the interval from 4 to 10 days) at least eight spikes (from each replication) were harvested and only kernels from the middle part were hand threshed and stored. The first sampling time was expressed by the number of days from anthesis to the beginning of milk maturity. Due to torrential rains at the beginning of July sampling time was not carried out in the regular intervals. Harvested grain samples were dried at the temperature $40^{\circ} \mathrm{C}$. Selected grain yield formation traits were evaluated during vegetation and maturity - stand of height, one thousand grain weight (TGW), portion of grain over the sieve $>2.5 \mathrm{~mm}$ (PGS) and volume weight.

Extraction of anthocyanins from wheat grain bran was accomplished according to the method described by Hosseinian et al. (2008). A ratio of wheat bran and solvent (methanol:1M HCl, 85:15, v/v) of $1: 8$ was used to extract anthocyanins. The samples were shaken at $300 \mathrm{rpm}$ for $45 \mathrm{~min}$ at room temperature and extracted twice. After extraction, the supernatants were collected. The crude wheat bran extract was separated by centrifuging at 5,000 rpm for $15 \mathrm{~min}$. The supernatant was concentrated under vacuum to dryness at $45^{\circ} \mathrm{C}$, resolved in methanol $(15 \mathrm{~mL})$ and stored at $4^{\circ} \mathrm{C}$.

Determination of total anthocyanins using the $\mathrm{pH}$ differential method. Total anthocyanins were measured by the method adapted from Fuleki and Francis (1968). Two dilutions of samples were prepared: one for $\mathrm{pH}=1.0$ using a potassium chloride buffer, and the other for $\mathrm{pH}=4.5 \mathrm{using}$ a sodium acetate buffer. The absorbance of each sample was measured at 520 and $700 \mathrm{~nm}$ against distilled water as blank. The total anthocyanin concentration was expressed as cyanidin-3glucoside equivalents $\left(\mathrm{mg} / \mathrm{dm}^{3}\right)$ :

$$
\frac{\mathrm{A} \times \mathrm{MW} \times \mathrm{DF} \times 10^{3}}{\varepsilon \times 1}
$$

where: $\mathrm{A}$ (the absorbance) $=\left(\mathrm{A}_{520}-\mathrm{A}_{700}\right)_{\mathrm{pHl}}-\left(\mathrm{A}_{520}-\mathrm{A}_{700}\right)_{\mathrm{pH} 4.5}$, $\mathrm{MW}=449.2 \mathrm{~g} / \mathrm{mol}$ for cyanidin-3-glucoside, $\mathrm{DF}=$ dilution factor, $\varepsilon=26,900$ molar extinction coefficient in $\mathrm{L} / \mathrm{mol} / \mathrm{cm}$, $1=$ pathlength in $\mathrm{cm}^{-1}$, and $10^{3}=$ factor for conversion from $\mathrm{g}$ to $\mathrm{mg}$. 
The concentration of total anthocyanins was re-calculated to $\mathrm{mg} / \mathrm{kg}$.

The data were analyzed by Statgraphics plus for Windows. Analysis of variance was conducted on the total anthocyanins concentration with sampling time as the factor and on the grain yield formation traits with genotype as the factor. Simple linear and polynomial regression response equations were determined for total anthocyanins concentration on the number of days post anthesis for each genotype.

\section{RESULTS AND DISCUSSION}

Genotype $62 / 0$ was 8 days later in heading and anthesis compared to cultivar Ilona; however, milk maturity was recorded one day earlier (Table 1). Genotypes of winter forms reached the physiological maturity in the same number of days from anthesis (42), during which spikes were sampled six times to determine total anthocyanins accumulation in the grain. Out of spring forms, the physiological maturity was earlier reached in genotype ANK 28A (10 days earlier compared to winter forms) and two days later in genotype UC 66049.

By visual observation we found out that blue pigmentation of genotype UC 66049 started in the basal part of grain, near by the embryo; and the whole grain was blue on the $24^{\text {th }}$ day post anthesis (Table 1). Intensity of blue coloring had an increasing trend until its maturity. In genotypes with purple color of the seed, coloring was firstly expressed in apical part of the seeds on the $12^{\text {th }}$ and $17^{\text {th }}$ day post anthesis for genotypes ANK 28A and 62/0, respectively. Genotype ANK 28A had on the third sampling time (22 days post anthesis) purple pericarp, but in genotype $62 / 0$ the purple color of grain was observed only on the $27^{\text {th }}$ day post anthesis (Table 2).

As expected, the highest total anthocyanins concentration in mature grain was observed in blue wheat UC $66049(193.38 \mathrm{mg} / \mathrm{kg}$ ) (Table 2), which is in accordance with the finding of Abdel-Aal et al. (2006), who indicated higher level of anthocyanins extracted from

$\mathrm{T}$ a $\mathrm{b} 1$ e 1

Dates of spikes sampling time of spring* and winter wheat genotypes expressed by number of days post anthesis

\begin{tabular}{|c|c|c|c|c|c|c|c|c|}
\hline \multirow{2}{*}{ Genotype/cultivar } & \multicolumn{2}{|c|}{ Date } & \multicolumn{6}{|c|}{ Sampling time } \\
\hline & heading & anthesis & 1 & 2 & 3 & 4 & 5 & 6 \\
\hline ANK 28A* & June, 5, 2011 & June, 12, 2011 & 8 & 12 & 22 & 26 & 32 & - \\
\hline UC 66049* & June, 3, 2011 & June, 10, 2011 & 6 & 10 & 14 & 24 & 28 & 34 \\
\hline $62 / 0$ & May, 24, 2011 & May, 31, 2011 & 13 & 17 & 22 & 27 & 34 & 42 \\
\hline Ilona & May, 16, 2011 & May, 23, 2011 & 14 & 18 & 25 & 30 & 35 & 42 \\
\hline
\end{tabular}

$\mathrm{T}$ a b 1 e 2

Mean concentration of total anthocyanins $[\mathrm{mg} / \mathrm{kg}]$ of spring* and winter wheat genotypes according to sampling time

\begin{tabular}{|c|c|c|c|c|c|c|c|c|}
\hline \multirow{2}{*}{$\begin{array}{l}\text { Genotype/ } \\
\text { cultivar }\end{array}$} & \multicolumn{6}{|c|}{ Sampling time ${ }^{* *}$} & \multirow{2}{*}{$\bar{x}$} & \multirow{2}{*}{$\mathrm{LSD}_{0.05}$} \\
\hline & 1 & 2 & 3 & 4 & 5 & 6 & & \\
\hline ANK $28 \mathrm{~A}^{*}$ & 40.47 & 95.33 & 291.07 & 55.75 & 37.80 & - & 104.08 & 42.14 \\
\hline UC 66049* & 14.61 & 117.88 & 50.18 & 171.37 & 173.29 & 193.38 & 120.12 & 28.74 \\
\hline $62 / 0$ & 124.09 & 91.83 & 179.53 & 81.00 & 56.32 & 34.50 & 94.54 & 28.19 \\
\hline Ilona & 8.74 & 13.36 & 6.28 & 6.73 & 3.10 & 2.37 & 6.76 & 1.90 \\
\hline
\end{tabular}

*** see Table 1 
wholemeal flour or bran of blue wheat compared to purple. The second highest total anthocyanins in mature grain was detected in genotype ANK 28A (37.80 $\mathrm{mg} / \mathrm{kg}$ ). The success of our local breeding was also by the fact that genotype $62 / 0$ reached the high total anthocyanins $(34.50 \mathrm{mg} / \mathrm{kg})$, which is comparable with parental line ANK 28A. Notable traits and properties of new genotype are similar to productivity of winter genotypes (Table 4), corresponding to the current cultivars registered and grown in the Slovak conditions. Ilona had in its maturity about $93.1 \%$ lower amounts of total anthocyanins compared to genotype 62/0 (Table 2). Significant variability in total anthocyanins in mature grains indicates that breeding for increasing its concentration is possible, which was also confirmed on a broader set of colored wheat by Knievel et al. (2009).

Both genotypes with purple color of grain had the highest anthocyanins on the $22^{\text {nd }}$ day post anthesis with a gradual increase and decrease before and after this sampling time (Figure 1, Table 2) mainly observed by genotype ANK 28A. Unexpectedly the second highest total anthocyanins was observed during the grain filling $(124.09 \mathrm{mg} / \mathrm{kg})$ in genotype $62 / 0$ on the $13^{\text {th }}$ day post anthesis (beginning of milk maturity) (Table 2). Genotypes with purple color of grain had approximately the

$\mathrm{T}$ a b 1 e 3

Simple linear and polynomial regression of total anthocyanins (y) on the number of days post anthesis (x) of spring* and winter wheat genotypes

\begin{tabular}{|l|l|c|}
\hline Genotype/cultivar & Simple linear response equation & $\mathrm{R}^{2}$ \\
\hline ANK 28A* & $\mathrm{y}=97.85+0.31 \mathrm{x}$ & 0.08 \\
UC 66049* & $\mathrm{y}=5.93+5.90 \mathrm{x}$ & $77.62^{++}$ \\
$62 / 0$ & $\mathrm{y}=174.52-3.01 \mathrm{x}$ & $42.84^{++}$ \\
Ilona & $\mathrm{y}=15.66-0.32 \mathrm{x}$ & $69.62^{++}$ \\
\hline & Polynomial response equation \\
\hline ANK 28A* & $\mathrm{y}=290.55+50.00 \mathrm{x}-1.26 \mathrm{x}^{2}$ & $55.18^{++}$ \\
UC 66049* & $\mathrm{y}=-26.7323+10.3498 \mathrm{x}-0.11 \mathrm{x}^{2}$ & $79.05^{++}$ \\
62/0 & $\mathrm{y}=106.18+2.73 \mathrm{x}-0.10 \mathrm{x}^{2}$ & $46.57^{++}$ \\
Ilona & $\mathrm{y}=13.91-0.18 \mathrm{x}-0.002 \mathrm{x}^{2}$ & $69.91^{++}$ \\
\hline
\end{tabular}

${ }^{++} P<0.01$

$\mathrm{T}$ a b 1 e 4

Average values of selected traits of spring* and winter wheat genotypes in 2011

\begin{tabular}{|l|c|c|c|c|}
\hline Genotype/cultivar & Stand of height $[\mathrm{cm}]$ & $\begin{array}{c}\text { TGW } \\
{[\mathrm{g}]}\end{array}$ & $\begin{array}{c}\text { PGS } \\
{[\%]}\end{array}$ & Volume weight [\%] \\
\hline ANK 28A* & $110^{\mathrm{d}}$ & 46.44 & $90.56^{\mathrm{b}}$ & $95.06^{\mathrm{d}}$ \\
UC 66049* & $100^{\mathrm{b}}$ & 44.65 & $95.04^{\mathrm{c}}$ & $88.36^{\mathrm{a}}$ \\
$62 / 0$ & $106^{\mathrm{c}}$ & 47.75 & $93.93^{\mathrm{c}}$ & $90.62^{\mathrm{b}}$ \\
Ilona & $88^{\mathrm{a}}$ & 44.84 & $87.75^{\mathrm{a}}$ & $92.84^{\mathrm{c}}$ \\
$\bar{x}$ & 101 & 45.92 & 91.82 & 91.72 \\
LSD $_{0.05}$ & 2.384 & - & 2.275 & 2.080 \\
\hline
\end{tabular}

TGW - one thousand grain weight, PGS - portion of grain over the sieve $>2.5 \mathrm{~mm}$

Different letters within the same column of each trait indicate significant differences at $P<0.05$ 
same concentration of total anthocyanins in the second sampling time; however, they differed in grain development (12 and 17 days post anthesis, respectively). Although the difference in total anthocyanins between ANK $28 \mathrm{~A}$ and $62 / 0$ in the third sampling time was $111.54 \mathrm{mg} / \mathrm{kg}$ against genotype 62/0, in the maturity it was minimized (only $3.3 \mathrm{mg} / \mathrm{kg}$ ). In both genotypes, the highest reduction in total anthocyanins was on the $26^{\text {th }}$ and $27^{\text {th }}$ day post anthesis compared to the former sampling time and it was of $80.8 \%$ for ANK $28 \mathrm{~A}$ and $54.9 \%$ for $62 / 0$. Knievel et al. (2009) reported that reduction of anthocyanins may be a result of dry matter accumulation in endosperm which is much faster than anthocyanins storage in aleurone and pericarp. In the second sampling time, which was 10 days post anthesis for blue grain genotype UC 66049, we unexpectedly found about eight times higher concentration of anthocyanins $(117.88 \mathrm{mg} / \mathrm{kg})$ compared to the first sampling time (6 days post anthesis). On the third sampling time
(14 days post anthesis), the concentration was reduced by $42 \%$ (Figure 2, Table 2), too. The reason of these differences is not clear yet; it is possible to explain it by subjective estimation of beginning of milk ripeness or variation of plants within a genotype. Bustos et al. (2012), for example, found out that grain position (in purple wheat genotype) affected grain weight and anthocyanin concentration, decreasing at distal position.

In the evaluated set, each genotype as well as cultivar Ilona responded differently to the dynamics of total anthocyanins accumulation during grain filling. Process of anthocyanins accumulation was described by linear and also by polynomial regression on the number of days post anthesis (next number of days) (Table 3).

At ANK 28A, dynamics of total anthocyanins accumulation described by linear regression on the number of days reached very low determination $\left(\mathrm{R}^{2}=0.08\right)$; however, by polynomial regression the de- $\mathrm{mg} / \mathrm{kg}$

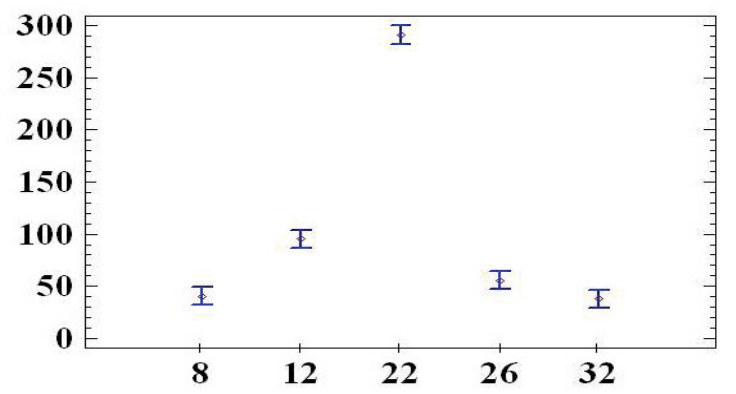

$\mathrm{mg} / \mathrm{kg}$

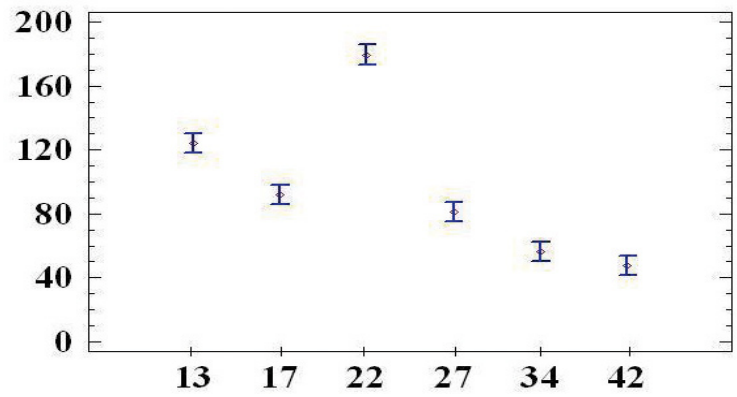

Figure 1. Trend of anthocyanins accumulation from the milk to physiological maturity ( $\mathrm{x}=$ days post anthesis) in genotypes ANK 28A (left) and 62/0 (right) of spring and winter wheat, respectively

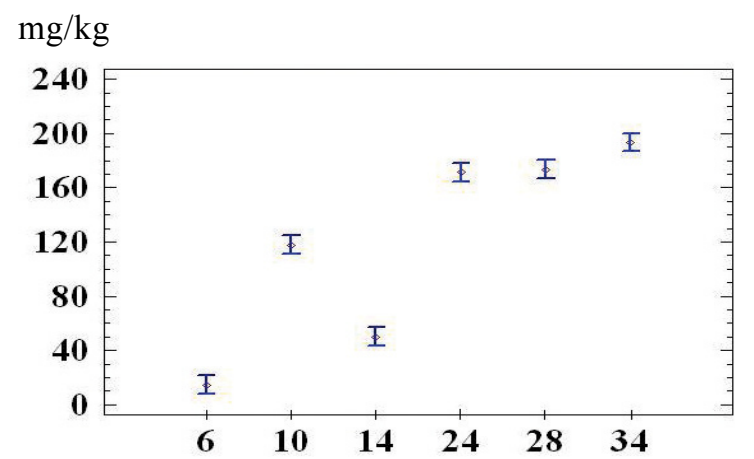

$\mathrm{mg} / \mathrm{kg}$

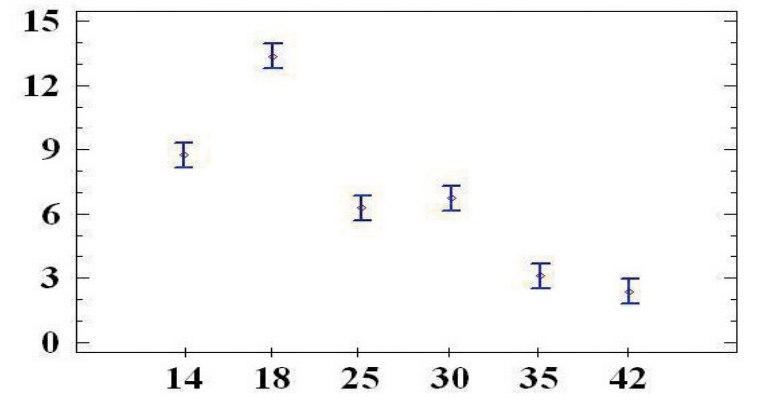

Figure 2. Trend of anthocyanins accumulation from the milk to the physiological maturity ( $\mathrm{x}=$ days post anthesis) in genotype UC 66049 (left) and cultivar Ilona (right) of spring and winter wheat, respectively 
termination was increased on the average $\left(\mathrm{R}^{2}=55.18^{++}\right)$ and after adjustation was particularized only on $\mathrm{R}^{2}{ }_{\text {adj }}=49.91^{++}$(not shown). Medium degree of determination was caused by high data dispersion from polynomial curve. On analysis it resulted that except number of days post anthesis another unknown factors affected dynamics of total anthocyanins accumulation. At UC 66049 genotype total anthocyanins accumulation was possible almost equally described by linear and polynomial regression on the number of days. Deviations of individual anthocyanins data from linear curve were relatively low $\left(r=0.881^{++}\right)$with the highest determination coefficient from evaluated set $\left(\mathrm{R}^{2}=77.62^{++}\right)$. According to the linear regression in UC 66049, total anthocyanins concentration was increased from the beginning of milk maturity by 5.906 $\mathrm{mg} / \mathrm{kg}$ per day and maximum value reached in grain physiological maturity. Although process of total anthocyanins accumulation is possibly deceptive to be described by linear and also polynomial regression on the number of days, parameter $\mathrm{x}^{2}$ was not significant and therefore linear model was valid. Similar process of total anthocyanins accumulation was at genotype $62 / 0$, where high total anthocyanins were detected at the beginning of milk maturity with consecutive reduction $-3.01^{++} \mathrm{mg} / \mathrm{kg}$ per day. At cultivar Ilona, determination of degree of total anthocyanins accumulation was equally described by linear and polynomial regression on the number of days, but linear one is valid as neither linear nor quadratic component was significant. Decreasing of anthocyanins concentration per one day at cultivar Ilona was 10 times lower than at genotype $62 / 0\left(b=-0.32^{++}\right)$.

Generally, different dynamics of total anthocyanins accumulation during grain filling can be also caused by different anthocyanins concentration in mature grain. For example at Ilona, average total anthocyanins concentration during grain filling was only $6.76 \mathrm{mg} / \mathrm{kg}$ (Table 2) and the maximum value was only two times higher in the second sampling time, which explained low value of regression coefficient (Table 3). On the contrary, genotype 62/0 had 14 times higher anthocyanin concentration in the first sampling time and equally in average during grain filling compared to cultivar Ilona. Effect of weather conditions during grain formation is also considerable. Heimler et al. (2010) found out in the set of old and modern durum and soft cultivars that temperature conditions 30 days before harvesting were the principal factor which differentiated the quantitative profile of polyphenols, and high temperatures caused a drop in their concentration. Our one-year observation on the narrow set of evaluated cultivars and an atypical course of weather in 2011 during grain filling period, however, does not entitle us to similar conclusions. Further research will concentrate on the analysis of weather factors.

\section{CONCLUSIONS}

At four colors of wheat genotypes, different dynamics of total anthocyanins accumulation during grain filling were caused by different anthocyanins concentration in mature grain. In purple pericarp wheats, during grain filling, the anthocyanin concentration increased and subsequently decreased prior maturity. In blue aleurone wheat, total anthocyanins concentration was reached in grain physiological maturity

Acknowledgments: The work was supported by the National Project of Research and Development "Biological and functional diversity of plant genetic resources in order to increase the added value of agricultural production" from the Ministry of Agriculture, Slovak Republic. The authors are grateful to Ing. Lubomír Rückschloss from the Research and Breeding Station at Vígl'aš-Pstruša for plant material donation.

\section{REFERENCES}

ABDEL-AAL, E.S.M. - YOUNG, J.C. - RABALSKI, I. 2006. Anthocyanin composition in black, blue, pink, purple, and red cereal grains. In Journal of Agricultural and Food Chemistry, vol. 54, 2006, pp. 4696-4704.

BAUBlis, A.J. - CLYDESDALE, E.M. - DECKER, E.A. 2000. Antioxidants in wheat-based breakfast cereals. In Cereal Foods World, vol. 45, 2000, pp. 71-74.

BOWEN-FORBES, C.S. - ZHANG, Y. - NAIR, M.G. 2010. Anthocyanin content, antioxidant, anti-inflammatory and anticancer properties of blackberry and raspberry fruits. In Journal of Food Composition and Analysis, vol. 23, 2010, pp. 554-560.

BUSTOS, D.V. - RIEGEL, R. - CALDERINI, D.F. 2012. Anthocyanin content of grains in purple wheat is affected by grain position, assimilate availability and agronomic management. In Journal of Cereal Science, vol. 55, 2012, pp. 257-264. DOI: 10.1016/j.jcs.2011.12.001

CHALKER-SCOTT, L. 1999. Environmental significance of anthocyanins in plant stress responses. 
In Photochemistry and Photobiology, vol. 70, 1999 pp. 1-9.

DUTHIE, S.J. - JENKINSON, A.M. - CROZIER, A. - MULLEN, W. - PIRIE, L. - KYLE, J. - YAP, L.S. - CHRISTEN, P. - DUTHIE, G.G. 2006. The effects of cranberry juice consumption on antioxidant status and biomarkers relating to heart disease and cancer in healthy human volunteers. In European Journal of Clinical Nutrition, vol. 45, 2006, pp. 113-122.

FULEKI, T. - FRANCIS, F.J. 1968. Determination of total anthocyanin and degradation index for cranberry juice. In Food Science, vol. 33, 1968, pp. 78-83.

HOSSEINIAN, F.S. - LI, W. - BETA, T. 2008. Measurement of anthocyanins and other phytochemicals in purple wheat. In Food Chemistry, vol. 109, 2008, pp. 916-924.

HEIMLER, D. - VIGNOLINI, P. - ISOLANI, L. -ARFAIOLI, P. - GHISELlis, L. - ROMANI, A. 2010. Polyphenol content of modern and old varieties of Triticum aestivum L. and T. durum Desf. grains in two years of production. In Journal of Agricultural and Food Chemistry, vol. 58, 2010, no. 12, pp. 7329-7334. DOI: 10.1021/jf1010534

KHLESTKINA, E.A. - ANTONOVA, E.A. - PERSHINA, L.A - SOLOVIEV, A.A. - BADAEVA, E.D. - BÖRNER, A. - SALINA, E.A. 2011. Variability of $R c$ (red coleoptile) alleles in wheat and wheat-alien genetic stock collections. In Cereal Research Communications, vol. 39, 2011, no. 4, pp. 465-474. DOI: 10.1556/CRC.39.2011.4.1

KNIEVEL, D.C. - ABDEL-AAL, E-SM. - RABALSKI, I. - NAKAMURA, T. - HUCL, P. 2009. Grain color development and the inheritance of high anthocyanin blue aleurone and purple pericarp in spring wheat (Triticum aestivum L.). In Journal of Cereal Science, vol. 50, 2009, pp. 113-120. DOI: 10.1016/j.jcs.2009.03.007

KONG, J.-M. - CHIA, L.-S. - GOH, N.-K. - CHIA, T.-F. - BROUILLARD, R. 2003. Analysis and biological activities of anthocyanins. In Phytochemistry, vol. 64, 2003, pp. 923-933.
LIU, R.H. 2004. Potential synergy of phytochemicals in cancer prevention: mechanism of action. In Journal of Nutrition, vol. 134, 2004, pp. 3479S-3485S.

MAZZA, G. 2007. Anthocyanins and heart health. In Annali dell'Istituto Superiore di Sanita, vol. 43, 2007 , pp. 369-374.

OOMAH, B.D. - MAZZA, G. 1999. Health benefits of phytochemicals from selected Canadian crops. In Trends in Food Science and Technology, vol. 10, 1999, pp. 193-198.

PRIOR, L.R. - WU, X. 2006. Anthocyanins: Structural characteristics that result in unique metabolic patterns and biological activities. In Free Radical Research, vol. 40, 2006, pp. 1014-1028.

QUALSET, C.O. - SOLIMAN, K.M. - JAN, C.C. - DVOŘÁK, J. - MCGUIRE, P.E. - VOGT, H.E. 2005. Registration of UC66049 Triticum aestivum blue aleurone genetic stock. In Crop Science, vol. 45, 2005, p. 432.

REVANAPPA, S.B. - SALIMATH, P.V. 2011. Phenolic acid profiles and antioxidant activities of different wheat (Triticum aestivum L.) varieties. In Journal of Food Biochemistry, vol. 35, 2011, pp. 759-775.

RYAN, K.G. - SWINNY, E.E. - WINEFIELD, C. - MARKHAM, K.R. 2001. Flavonoid and UV photoprotection in Arabidopsis mutants. In Zeitschrift für Naturforschung, vol. 56c, 2001, pp. 745-754.

TREUTTER, D. 2006. Significance of flavonoids in plant resistance: a review. In Environmental Chemistry Letters, vol. 4, 2006, pp. 147-157.

WANG, LI-S. - STONER, G. D. 2008. Anthocyanins and their role in cancer prevention. In Cancer Letters, vol. 269, 2008, pp. 281-290.

Received: May, $10^{\text {th }}, 2012$ 